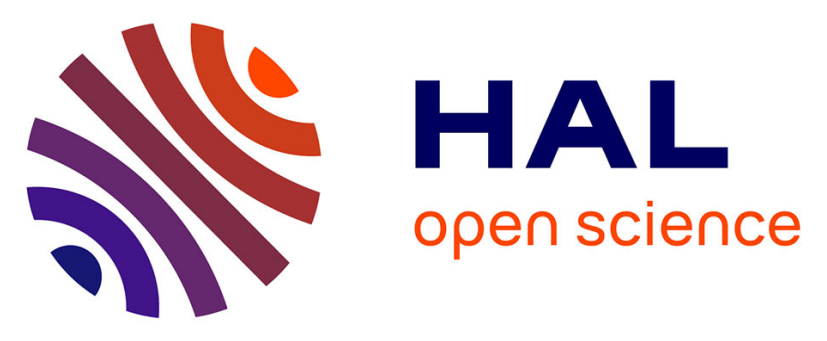

\title{
Robust nonsingular fast terminal sliding-mode control for Sit-to-Stand task using a mobile lower limb exoskeleton
}

Joel Hernandez Hernandez, Sergio Salazar, Ricardo López-Gutiérrez, Arturo

Gonzalez Mendoza, Rogelio Lozano

\section{To cite this version:}

Joel Hernandez Hernandez, Sergio Salazar, Ricardo López-Gutiérrez, Arturo Gonzalez Mendoza, Rogelio Lozano. Robust nonsingular fast terminal sliding-mode control for Sit-to-Stand task using a mobile lower limb exoskeleton. Control Engineering Practice, 2020, 101, pp.104496. 10.1016/j.conengprac.2020.104496 . hal-02947788

\section{HAL Id: hal-02947788 \\ https://hal.science/hal-02947788}

Submitted on 13 Dec 2020

HAL is a multi-disciplinary open access archive for the deposit and dissemination of scientific research documents, whether they are published or not. The documents may come from teaching and research institutions in France or abroad, or from public or private research centers.
L'archive ouverte pluridisciplinaire HAL, est destinée au dépôt et à la diffusion de documents scientifiques de niveau recherche, publiés ou non, émanant des établissements d'enseignement et de recherche français ou étrangers, des laboratoires publics ou privés. 


\section{Robust nonsingular fast terminal sliding- mode control for Sit-to-Stand task using a mobile lower limb exoskeleton论}

Author links open overlay panelJoel HernándezHernándezåSergio

SalazarCruz RicardoLópez-Gutiérrez ${ }^{\mathrm{D}}$ ArturoGonzález-Mendoza'RogelioLozano ${ }^{a c}$

https://doi.org/10.1016/j.conengprac.2020.104496Get rights and content

\section{Control Engineering Practice}

Volume 101, August 2020, 104496

\section{Highlights}

Numerical simulations.

RNFTSMC vs Super Twisting controller.

Trajectory tracking.

Convergence in finite time.

Compensation of matched and unmatched disturbances (such as the mass change).

Reduction of the chattering effect produced by the slow frequency of actuators.

Discontinuous controller.

\section{Abstract}


In this paper, a Nonsingular Fast Terminal Sliding Mode Control (RNFTSMC) is proposed to regulate the position of a mobile lower limb exoskeleton powered by linear actuators with four degrees of freedom. The developed lower limb exoskeleton has the purpose to assist the sit-to-stand and stand-to-sit tasks for people with spinal cord injury (SCI) or elderly people. Currently most of the developed lower limb exoskeletons are dealing with the presence of uncertainties (unmodeled dynamics) and external disturbances (mass changes, opposite forces), caused by the high complexity of the human limbs dynamics. The RNFTSMC has the purpose of dealing with these uncertainties, ensuring a rapid convergence in finite time to the desired position, and reducing the chattering effect produced by the nature of the controller actuators.

The human intention movements have been detected using an sEMG signal classifier performed by the Myo Armband device and processed to activate the preprogrammed routines in the RNFTSMC. The desired paths for the knee and hip exoskeleton joints were obtained by recording data from a volunteer who rises from a chair and sat on it, using a motion capture system. To evaluate the effectiveness of the proposed control scheme, real-time experiments under three different scenarios have been carried out.

\section{Graphical abstract}

